\title{
Our Role in the Quickening Pace Towards Independence in Africa
}

\author{
By Joseph C. Satterthwatte
}

Abstract: Our belief in the self-determination, self-government, and independence of peoples has persisted throughout American history. The rapid political and social changes that are occurring in the countries of tropical Africa have drawn our sympathy and, in a more active way, have drawn our support through material and technical assistance granted to them directly or through the organization of the United Nations. It is of fairly recent date that the United States has officially co-operated in this area, an area that was previously a sphere in which European interests were predominant. While we have begun to offer assistance to the African states, we are hopeful, at the same time, that the long-established ties with the European countries can continue in another form, advantageous to both. The needs, we recognize, of the African states are of such magnitude that they cannot be fulfilled by any one country. We have, therefore, co-operated in efforts to promote economic development initiated by the United Nations and its specialized agencies. We are being called upon more and more to share our material benefits with the less-developed parts of the world. The African states form one of these areas, indeed a very important one, and we are ready to play our role in responding to their needs.-Ed.

Joseph C. Satterthwaite, A.M., LL.D., Washington, D. C., has been AssistantSecretary of State for African Affairs since 1958 when the post was created. He entered the Foreign Service in 1926 and his varied career has been spent in Germany, Mexico, Argentina, Iraq, Turkey, Syria, Nepal, and Morocco. Mr. Satterthwaite has also been Ambassador to Ceylon and Burma, Director of the Office of Near Eastern and African Affairs, and Director-General of the Foreign Service. He is a graduate of the University of Michigan. 
$I^{1}$ $\mathrm{T}$ is my intention to discuss briefly why and how we, as Americans, are involved in the nationalist ferment in Africa and what the future may hold for our relations with the independent states. Major attention has already been given to the northern and southern areas of the continent. The northern area is the focus for another paper in this volume. And the position of the United States toward recent developments in the Union of South Africa has been made known both in Washington and at the recent meeting of the Security Council. My remarks are accordingly directed in general to the great belt of tropical Africa where at present social and political changes are moving at a rapid pace.

\section{Our Moral and Historic Role}

I think it may be held that since the American Revolution, the American people have been involved in the movement of any peoples anywhere in the world toward self-determination, selfgovernment, and independence. The founders of our nation and our great statesmen have fully realized and articulated this fact, knowing that the principles on which our independence was based would have effect far beyond their time and beyond our shores. Abraham Lincoln called for the blessings of liberty for all mankind believing that neither his country nor the world could long survive half free and half slave. In the rush of modern events, I think we sometimes forget the strong and enduring currents which our example set in motion. We do not, of course, have a monopoly on these ideals for they have been given impetus by the great liberal societies of Europe and have been jointly enunciated in such historic documents as the Atlantic Charter.

The events of the twentieth century have brought to the surface a new wave of change which has carried hundreds of millions of people to independence in Asia, in the Arab world, and now in tropical Africa. Here "freedom" in various languages is the catchword. The old slogans and declarations of our independence struggle have been revived with undiminished force and meaning. These phenomena stir a spontaneous response and welcome in the American people because they spring from the same soil in which our own past is rooted.

America also has ties with Africa of a more tangible kind. About one tenth of our population has its origin in tropical Africa. We have, therefore, a special interest in events in Africa, an interest, however, which is by no means confined to those of our population who had their origin on that continent and who have contributed so much to our culture and its expression. I might also observe that our own problems of assimilating Americans of African descent into our free society, an issue involved in our Civil War, should make us view with some humility the present problems of the European populations which now control the "multiracial" states in Africa.

Again on the very tangible side, we helped to establish over one-hundred years ago the free state of Liberia as a home for freed slaves and as an example of the principle of self-government which remained unique in tropical Africa until the twentieth century. Its name, "Liberia," proclaims its status, and its capital, Monrovia, commemorates the President under whose administration it was founded. Our government has always had close and friendly relations with Liberia, and American investment and free enterprise continue to have an important influence on the development of its economy.

Our governmental and cultural rela- 
tionships with Africa by no means exhaust our long-term historic association. American missionaries in large numbers have had an important influence quite apart from their evangelical mission. Their mission schools have provided primary and secondary education to promising students who had nowhere else to turn. These men and women now form part of the leadership group who will have to cope at various levels with the independence which their people have achieved or may achieve. Some few of them have gone on to universities in the parent country or in the United States. I think it significant that from this number have emerged such leaders as Prime Minister Nkrumah of Ghana, Julius Nyerere of Tanganyika, and Dr. Asikiwe of Nigeria. Viewed especially in the light of present conditions, the educational service performed over a long period of years by American and other Christian missionaries in Africa will have an abiding beneficial influence on the new societies now being formed.

American private enterprise, private foundations, and education have had a significant influence in Africa. The preponderance of investment has been in the industrialized Union of South Africa, in Liberia, and the Rhodesias, but it is increasing in those newly independent countries which have established a friendly climate for foreign capital. The foundations are conducting research and consultative and educational programs in many countries which have achieved or are on the way to achieving independence. The metropolitan and local governments generally have welcomed these efforts, and their work and training will be of great assistance not only to new governments when they emerge, but also to the United States government and private enterprise in planning future aid and investment programs.

\section{Our Proper Contemporary Role}

Now I would like to turn to our proper contemporary role in Africa. I shall confine my remarks largely to the role of government. I use the word "proper" advisedly because we are admonished by some to "keep hands off" and urged by others to champion the growing nationalist movement in Africa. We are charged on the one hand with interference, on the other with irresponsible indifference. We likewise face the accusation that our sympathies are entirely with African aspirations and that we are prepared to abandon European and other minority groups who have made their permanent home in Africa. We do not, of course, subscribe to the belief that any race or individual in Africa is expendable. Each can play an important role in the future development of Africa. Between these extremes we must pursue a course best calculated to serve the long-term interests of the peoples of the United States, of Africa, and of the free world in general. I say "proper," also, because we did not play a major role in Africa during the last century, whereas our European allies have major interests of long standing on that continent. The drama now unfolding is one, therefore, in which the Africans and Europeans play the major parts. Our course, in view of our varied and sometimes conflicting interests, is often difficult to chart. However, we shall not go astray if we continue to be guided by our firm belief in the evolution of peoples to self-government and independence by peaceful means, our traditional willingness to offer moral and material assistance to peoples striving to maintain stable representative governments, and our readiness as a member of the United Nations to help defend duly constituted governments and their peoples against aggression.

In tropical Africa the evolution to- 
wards independence has been and continues to be remarkable for the speed and nonviolence of the transition. This has required statesmanship, tolerance, and goodwill of a high order on all sides-by the Africans who are imbued with ardent nationalism and are impatient of delay, and by the European powers who are faced with major political, economic, and psychological decisions and adjustments. Our proper role as a government is to play the role of a friend contributing to orderly transition while hoping that new, strong, and voluntary ties will be established between the new countries and the former administering states. Certainly both stand to gain from such a relationship.

I do not mean to indicate from the foregoing that the United States has no official presence in African countries while these changes are going on or until they become independent. On the contrary, we have one or more Foreign Service establishments in most of the political subdivisions of the continent, twenty-nine United States Information Service establishments, as well as International Co-operation Administration representatives, and programs in Overseas Territories. We have embassies in eleven independent countries. Significant, if modest, educational exchanges are taking place, and the President's Cultural Presentation Program is bringing American artists, musicians, and athletes before African audiences. In 1958 and 1959, Prime Minister Nkrumah and President Touré of Ghana and Guinea, respectively, paid visits to the United States at the invitation of President Eisenhower. Such visits express the profound interest and respect of the American people and government for these new nations and their leaders as they embark on the difficult course of liberty.

I should like to comment here on the frequently expressed doubts or fears as to whether the people of Africa are yet ready to run their own affairs, whether they have sufficient experience with selfgovernment to assume its responsibilities, whether they will not fall victims of governments of the extreme right or left. I believe history has shown that "readiness" is almost an academic question. Peoples tend to acquire independence, whether they are ready or not, according to a timetable more or less of their own making. The degree of experience with self-government varies with the type of tutelage received from the mother country. In tropical Africa, for example, we are witnessing the imaginative evolution of the French community. Its members have moved in a short period of time from typical colonial status towards self-government or independence. Nigeria, a British colony, has benefited in an exemplary manner from education and civic training and guidance provided by Great Britain in preparation for independence in October 1960. We have the dramatic instance of the Belgian Congo where six months ago neither the people of that area nor the Belgian government would have predicted the independence which will come on June 30 of this year. Yet the colonial government with outstanding statesmanship has negotiated with Congolese leaders for the transfer of power under the optimum conditions time will allow.

Turning to the character the new governments will have, I believe, on the basis of past and present experience, we have reason to be optimistic. Elections, both in still dependent and in independent areas, have been generally peaceful, impressive, and marked by a very large turnout of voters. The new governments are responsive to the will of the people and have the support of the majority of the populace. In some cases there is not the same respect for the minority opposition that is custom- 
ary in Western democracies. However, we cannot expect Africa to follow entirely Western patterns in developing democracy. Ancient African local governmental processes accept as binding the consensus of the majority. And in African societies where the tribal and chieftain system prevailed those who opposed this consensus had to be silent or leave the group; a system which we might consider autocratic. What we can hope for with considerable confidence is the steady growth of democratic principles based on respect for human rights, justice, and law. We must expect a certain instability and trial and error. These are, after all, the normal problems of democracies which we experienced in full measure during the first decades of our independence. What would be most helpful at this time, it seems to me, is continuing evidence of America's understanding, confidence, and willingness to assist during the years of growth and adjustment ahead.

\section{AMERICA's ECONOMIC InVOLVEMENT}

Both African and outside observers agree that for a long time to come the principal assistance required by the emerging states of tropical Africa is, first, education and training-using those terms in their broadest senseand second, development assistance, which includes private investment and public financing. President Sekou Touré of Guinea when he was in the United States made the pointed observation that to Africans the world is divided into two parts: not free and communist, but developed and undeveloped, and that they would seek development assistance from wherever they could receive it, without regard to political considerations.

It is perfectly clear that Africa's needs are great, so great that they cannot be provided by any one country. The metropolitan powers have, during the period of dependence, provided major economic assistance both for development and in the form of administrative expenditures. In general, it seems that substantial assistance from the metropolitan powers will continue during and after the transition period to independence. The value of this type of support for last year is estimated at over $\$ 500,000,000$. But independence shifts certain burdens and the metropolitan powers are unlikely to continue to provide all the costs of an administration which they have relinquished.

The United States has but lately become involved in providing a share of the educational, technical, and development assistance so urgently needed in tropical Africa. Interest of American private investment in West Africa is strong and, given a continued receptive climate, should increase. The government, the private foundations, and our universities are making a significant beginning by provision of educational and training assistance for the future leadership. There are now over 1,700 African students in the United States. But by contrast, there are some 10,000 in the United Kingdom, a similar number in France, and an undetermined number in Communist-bloc countries. Next year our government hopes to finance 500 educational exchanges, 400 of them to bring Africans to this country, 100 for American teachers, professors and specialists to work on the African continent.

Now, these are good beginnings but they are not good enough. The facts are that countries are approaching political independence without sufficiently trained leadership and technical and managerial skills and without firmly established economic and social institutions and systems which provide the foundations for secure, confident, African-governed nations. Present United 
States foreign assistance programs are not adequate in scope or size to be responsive to the dramatic changes taking place. As the most materially favored nation in the free world community, we must accept a larger responsibility in meeting this challenge. The executive branch has, therefore, proposed to the Congress a special program for tropical Africa with an initial appropriation of $\$ 20,000,000$ under the Special Assistance category. We have a fresh situation; we are attempting to meet it in a fresh manner. President Eisenhower in presenting this proposal to Congress said: "It is my belief that this initial effort must be increased significantly in the immediate years ahead and complement similar efforts on the part of other free world nations so that the capacity of the new and other developing nations in Africa to manage and direct their development can be strengthened and increased rapidly and effectively."

The essential character of the special program for tropical Africa lies in its intensive concentration on key education and training problems and on regional activities. It would not replace our bilateral technical co-operation under the International Co-operation Administration, but it would be closely related to it. It is not intended that it should become a competitor to or substitute for assistance from other free world sources. It is our hope, rather, that it may serve to encourage an increase in assistance from other free world countries and international and national organizations.

\section{Development Advisory Group}

I mentioned earlier that no single country could possibly provide the economic and technical assistance required by Africa in the coming years-a continent of over $220,000,000$ people, over three times the area of the United States, and undeveloped in the mid- twentieth-century sense of the term. Recognizing this, and also the fact that a number of our allies are providing bilateral assistance to a number of undeveloped countries, Under-Secretary of State Douglas Dillon suggested to the European countries in January that the principal capital exporting countries meet to discuss various aspects of cooperation in their assistance efforts. The suggestion was accepted and last month the group held its first meeting in Washington. Known as the Development Advisory Group the members are: Belgium, Canada, France, the Federal Republic of Germany, Italy, Japan, Portugal, the United Kingdom, the United States, and the Commission of the European Economic Community.

At this meeting primary attention was directed towards methods and means of improving the flow of bilateral aid. Members reported on their experience and problems in extending, financing, and promoting economic development in the less-developed areas. They heard reports from the International Bank and the International Monetary Fund. Significantly, I think, the Group agreed that its efforts should not involve discussion of amounts of financing for particular regions, countries, or projects. In other words, it is not another operating agency but a facilitating, ways and means body. This should allay the fears expressed by some undeveloped countries that the capital exporting states plan to "gang up" on them, make decisions affecting them without consultation, and keep them in a position of suppliers of raw materials to the industrialized economies. Nothing could be farther from the truth. The Group plans to continue its activities through meetings at regular intervals, the next to be in about three months in Bonn, Germany.

A somewhat detailed discussion of the Development Advisory Group has 
been given because it could be a very important step towards reconciling our own and other free world countries' sometimes disparate approach to the joint problems of furnishing economic aid. It is a step away from "going it alone" and towards co-operative efforts. As one commentator expressed it, "the Conference well might become a beacon of hope in a vast economic wasteland." As one of the largest underdeveloped areas of the world Af. rica could be a principal beneficiary of its work.

In considering the whole area of economic, technical, and educational assistance, we are too often inclined to act, I think, as though all motivation rests with us, "us" meaning the developed countries. This is not a healthy or natural situation. Important initiatives are also required of the countries and territories to be assisted. We may take the area under discussion this afternoon as an example. As states in tropical Africa move toward independence, we need to know with some preciseness their own estimate of their needs. It is not sufficient to say, "we need everything." We cannot plan or budget on that basis, and "shotgun" aid is likely to have a worse effect than none. New states must put their own economic and fiscal houses in order so that aid can be efficiently channeled. There must be an understanding of the processes through which assistance funds are appropriated in democratic countries. Our Congress has an inescapable accountability to the taxpayer for the use of his money, and I would hope that recipient countries would understand this and not regard certain strictures on the use of grant or loan funds or technical assistance as evidence of "political strings" on the part of the United States. While we must cut the red tape that sometimes binds our aid programs, some controls over them are a mark of responsibility. In the field of free enterprise, new governments must create conditions that will make capital investment and development attractive or it will go elsewhere.

\section{The Regional Approach}

Particularly in Africa there would seem to be advantages in a regional approach to assistance. The boundaries of the present political divisions of the continent were in many instances arbitrarily drawn and often prevent the undertaking of economically or socially viable projects.

It is encouraging that African leaders are aware of this problem and are giving some consideration to area planning from the development point of view. We can, I think, do much to encourage such regional and co-operative approaches to the many common developmental problems which confront all the African countries. For example, in planning the special program for tropical Africa which I mentioned earlier, we are proposing to use a portion of the funds requested to support and sponsor multi-country conferences, workshops, and seminars as training programs in themselves and as a means of stimulating co-operative approaches to special development problems, such as the tsetse fly which closes large parts of the continent to livestock raising. In the field of education we will propose a training grant program which will permit Africans from several countries to attend various African schools and colleges.

I would make one further remark on the subject of economic assistance. Aimless benevolence is not the objective of our foreign assistance programs. Our objective is to strengthen the economies of underdeveloped states and enrich the lives of their people so that democracy will be satisfying and meaningful to them. We believe that such objectives 
are in our mutual interest. To accomplish them efficiently, there must be responsive initiatives from the co-operating countries.

We must recognize, of course, that the whole question of regionalism in Africa is a complex and difficult subject with far-reaching political overtones. While I believe that closer associations of African countries will develop, it will be a long process and it is a matter which the peoples themselves will have to effect.

In this connection it is pertinent to quote from the speech made by Secretary of State Herter earlier this week in Chicago at the 38th Annual Convention of the National Association of Broadcasters. Referring to efforts which the United States is making to build closer relations with the new African nations and the concern which we have for their welfare and security as they assume the responsibilities of independence, he said: "It is our hope that they can devise regional arrangements to insure the peaceful settlement of disputes and to avoid a wasteful and dangerous arms race. This would indeed be a forward step toward insuring peaceful change."

\section{COMmunism and Africa}

It is not the purpose of this discussion to study communist influence and involvement in Africa but I believe I should mention it if for no other reason than to avoid misunderstanding. The forces of international communism are fully aware of the opportunities present to exploit the nationalist movement in Africa for their own political ends. They have been doing so at an increasing rate, covertly through their usual methods and overtly through rather massive economic and technical assistance in chosen areas. I think it is testimony to the stability and good sense of the African people that commu- nism has not gained a significant foothold on the continent. The policy of "positive neutrality" enunciated by some African leaders sometimes leads us to the view, erroneously I think, that the new African states are "soft" on communism. There is more evidence, I believe, that Africans who have but recently freed themselves of foreign control will not, except by force, permit themselves to come under a new domination alien to them in every sense of the word.

I would not be honest if I did not admit that we are concerned over the impressive assistance offers that the Communist bloc have made in Africa in the last year or so. If these programs were only what they seem on the surface, aid to the economy and technology of underdeveloped societies, there would be little cause for concern. It is not reasonable to assume that new governments in dire need of the assistance of technically developed peoples would refuse to accept such aid. The legitimate concern, it seems to me, stems from the fact that communism uses all means to attain the political objective of communization and control. Economic "cooperation" is only one means, but it could be an effective one when applied to peoples who lack an established political and economic order of their own. However, there are many indications that the African peoples and leaders will be vigilant and uncompromising in rejection of all political subversion masquerading as friendship and assistance.

Our own expanding programs of cultural, technical, and economic collaboration with Africa stem from the traditional character of our society which has demonstrated time and again our conviction that to help others help themselves is the path of enlightened self-interest. Our motives are, and must remain, positive and not negative-for a better way of life for 
Africans, not against a communist initiative here and there. We have no desire to see Africa become a "cold war" battleground. Such a development would be as distasteful and unproductive for Africans as for the rest of the free world. We believe that the maturing "African personality," while unique, has already cast its lot with free men.

\section{The United Nations and Africa}

No discussion of America's relationship to Africa would be complete without mention of the United Nations. Additional contact with Africa comes about through our participation in the United Nations and its specialized agencies. For example, as members of the Trusteeship Council we have had a voice in the future of the trust territories in Africa, although all seven of them are or were administered by various European powers. I think it is fine testimony to their administration and to the effectiveness of the United Nations system that three of these trust territories, Cameroun, Togo, and Somalia, have been or will be granted independence in 1960, and that one other, British Cameroons, may determine its future status within the year. The British Cameroons elected to postpone the decision in a plebiscite held under United Nations auspices last fall. The United Nations has so far been unsuccessful, I regret to say, in its efforts to have Southwest Africa put under trusteeship or under some other form of international supervision. It remains under mandate to the Union of South Africa where it was placed by the now defunct League of Nations.

The United States is a strong supporter of the United Nations technical assistance programs and of the specialized agencies working in the fields of health, agriculture, and education. We are also the largest contributor of funds to these agencies and to the United
Nations Expanded Technical Assistance Program. I think it is sometimes forgotten that the United States assessment represents about a third of the total budgets of the various specialized agencies, and its voluntary contributions amount to 40 per cent of the total funds available to the Expanded Technical Assistance Program and to the United Nations Special Fund. By formula we agree to maintain this ratio as other countries increase their contributions. In other words, the amount of our assistance is tied to the confidence which other members indicate by their support of the specialized agencies and United Nations technical assistance.

In this connection, we have noted the strong preference which some leaders of independent African nations have expressed for assistance through the United Nations rather than through bilateral assistance. Some of them may fear that bilateral assistance will involve excessive dependence upon other nations, or that such assistance would entail conditions which might detract from their sovereignty. While there are certain conditions attached to virtually all forms of aid, multilateral as well as bilateral, we believe the record of the United States and other free nations in supplying economic aid and technical assistance clearly demonstrates that such aid will not be used to impair the freedom or independence of any nation. At the same time, there are sometimes definite advantages connected with aid through the United $\mathrm{Na}$ tions, and we believe that both United Nations sources and other sources will be needed. As I have noted, our government is the heaviest investor in the United Nations' programs. As more African countries attain independence, I foresee their sharing to an increasing extent in the benefits of these programs. I also believe that the dynamic develop- 
ments on the continent increase both the obligation and the opportunity for the United Nations to expand its work. The Economic Commission for Africa, established with headquarters in Addis Ababa in 1958, should give new impetus to the planning of effective programs to meet the social, economic, and technical needs of the African people. The United States has observer status on this Commission and is following its progress with keen interest.

Through the United Nations our government also becomes involved in Africa's political and social problems; and, conversely, the increasing representation of African states in the world organization is having a growing impact. The one-nation one-vote system in the General Assembly means that Africa may, before very long, be able to influence strongly the resolutions of that body which tend to reflect world opinion. In the past we have frequently found ourselves at variance with the African states on issues which, we think, they tend to view from a local or continental vantage point. It is understandable that these new countries should, at the outset, be primarily concerned with African problems and attempt to avoid entanglement in wider issues which, they may feel, they had no part in creating. But it is our hope and expectation that time and experience and the full acceptance of African countries into world councils will bring us closer together on positions which the United Nations can take to advance peace, security, and international amity.

\section{ConcLusion}

The question posed in that part of this symposium dealing with Africa is whether America is involved in the nationalist ferment in Africa. I believe it is now evident that the United States and the American people do have a significant involvement in African affairs and, inevitably, in the nationalist ferment now taking place on that continent. In the past, this involvement has been important but limited and sporadic. However, with a dramatic new era dawning over Africa, we are called upon to play a new and, I think, a more positive role in responding to the needs of these countries and in sharing with them our human and material resources. We shall not play it alone but in concert with others and with the United Nations. The United States has strong historic, cultural, economic, and linguistic ties with tropical Africa. They are invaluable assets with which to develop new bonds with the peoples of Africa who are looking to the United States to see what response to their needs and problems will be forthcoming. I am sure we shall not be found wanting.

\section{QUESTIONS AND ANSWERS}

Q: Some of us in the University Extension Association feel that most of the efforts toward educating the adults in world affairs in the past ten years have been considerably less than effective. Secondly, we feel that part of the reason for this is that the universities have not played so large a role in educating
American adults about world affairs as they should have. Africa especially has been one of the neglected areas in this adult curriculum. What might we as academics, as scholars, as people interested in world affairs do to offer the American public some greater education, not simply awareness, not simply propa- 